\title{
„GESCHWISTER, RETTET UNS GESCHWISTER“ LOVE BETWEEN SIBLINGS AS A RELIGIOUS ISSUE FROM EURIPIDES'S IPHIGENIA TAURICA TO GOETHE'S IPHIGENIE AUF TAURIS
}

\begin{abstract}
Summary: This article compares Euripides's Iphigenia Taurica with Goethe's Iphigenie auf Tauris, and investigates how the theme of love between siblings is related to the religious issue in both tragedies. I firstly analyze how, in the Euripidean tragedy, the value of familial love can connect the two worlds of gods and humans, thanks to the parallel between the human (Iphigenia and Orestes) and the divine couple of siblings (Artemis and Apollo). By sharing this human value, the gods demonstrate that they can be different from the immoral deities depicted in myth, and correspond to Iphigenia's ethically purified image of them. However, the Euripidean plot included at least three elements which an Eighteenth-century intellectual could not accept (paragraph three): the obscurity of the divine messages; the centrality of theft and cunning; the inability of men to solve the tragic predicament autonomously. The value of family affection is momentous for the removal of those elements (paragraph four): in the Goethean play, the Gods demonstrate that they share it not by directly intervening, but by providing the human sister with the powers of the divine sister: therefore, Iphigenia can heal her brother, and the statue of Artemis need not to be stolen. Iphigenia proves that the gods speak to the human heart, and in this way the problem of communication with the supernatural sphere is solved.
\end{abstract}

Key words: reception of the Euripidean tragedy, Euripides and Goethe, tragedy and religion

\section{PREMISE: GOETHE'S ATTITUDE TOWARDS EURIPIDES}

Most critical literature on Goethe's Iphigenie auf Tauris understands it in terms of rupture and distance from the ancient model; however, this critical attitude prevents us from correctly understanding how Goethe reworks the Euripidean tragedy. A more convincing approach is instead shown in an article by B. Zimmermann, where the scholar points out that it can be understood as an attempt to "improve" the Euripidean play. In Zimmermann's view, the German writer found in Euripides a potential for "Enlightenment" ideas, concerning society - especially the social role of women and religion, which he could further develop: 
[E]s ist gerade der aufklärerische Tenor, der Goethes Iphigenie auf Tauris mit der euripideischen Iphigenie bei den Taurern und überhaupt mit der gesamten euripideischen Tragödie verbindet. Die Änderungen, die Goethe gegenüber dem euripideischen Original vornimmt, lassen sich daraus erklären, daß Goethe das euripideische Stück noch euripideischer machen wollte, es konsequent euripideisch umschreiben wollte.

It is precisely this Enlightenment tone that connects Goethe's Iphigenie auf Tauris with the Euripidean Iphigenia Taurica and with the whole Euripidean tragedy. The changes to the Euripidean model are motivated by the desire to make the Euripidean play even more Euripidean, and consequently rewrite it in a Euripidean way. ${ }^{2}$

Zimmermann specifies that Goethe wanted to make Euripides "more Euripidean" according to the characterization of Euripides contained in Johann Georg Sulzer's Allgemeine Theorie der schönen Künste (dated 1771-1774), a book which highly influenced Goethe's views on classical Greek theatre. There Euripides is praised for his ability to depict the female characters, as well as for his engagement against false religious doctrines, which, according to Sulzers, was due to his being a pupil of Socrates. $^{3}$

In this article, I shall concentrate on the religious aspects of Goethe's reworking of the ancient model. I shall point out that the theme of family love plays a major role in the religious message of Goethe's play, and that this connection with religion has its premises in the Euripidean model.

In fact, Sulzer's opinion that Euripides attended the "school" of Socrates is nowadays untenable, and figuring him out as an Enlightenment intellectual engaged in a battle against superstition is hardly convincing. Nevertheless, it is true that reflection on religion plays a relevant role in the Euripidean tragedies, and especially in $I T{ }^{4}$ The most interesting lines are 380-391, where Iphigenia engages in a polemic against the traditional conception of divinity:

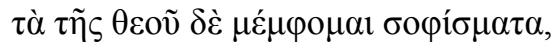

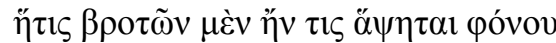

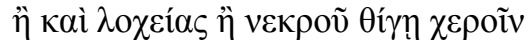

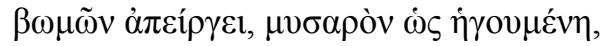

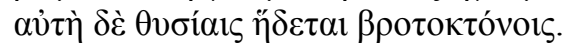

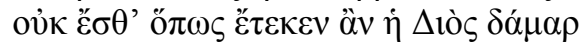

\footnotetext{
${ }^{1}$ ZimmermanN, B.: Euripides' und Goethes Iphigenie. In »...auf klassischem Boden begeistert«: Antike-Rezeptionen in der deutschen Literatur. Hrsg. O. HILDEBRAND - T. PITTROF. Freiburg i. Br. 2004, 133-143, here 137.

${ }^{2}$ Unless otherwise specified, translation of quotes in languages other than English are mine.

${ }^{3}$ SUlzER, J. G.: Allgemeine Theorie der schönen Künste. Leipzig 1771-1774, 152, 154, quoted in ZimMERMANN (n. 1) 136. On the opinion that Euripides was Socrates's pupil cf. PETERSEN, U.: Goethe und Euripides. Heidelberg 1974, 30 n. 6.

${ }^{4}$ Euripides's understanding of religion has been studied extensively in secondary literature. For an introduction to the topic, see PUCCI, P.: Euripides's Revolution under Cover. Ithaca, NY 2016.
} 


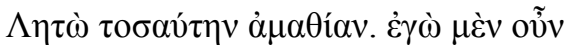

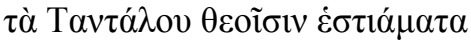

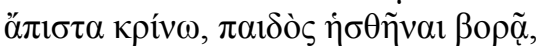

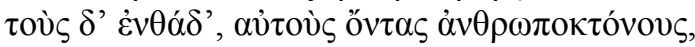

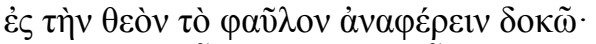

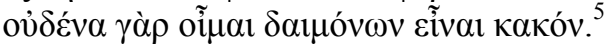

Iph. As for the goddess' wisdom, I deplore it. When any of us mortals has contact with bloodshed, or even touches childbirth or a corpse with their hands, she bans them from the altars, judging them polluted - while she herself relishes human sacrifices. In no way could Zeus's consort Leto have given birth to such uncouthness! I for my part do not believe the story of Tantalus' feast for the gods - that they relished a meal of his son! The people here, I think, being murderous themselves, ascribe their weakness to the goddess. I do not believe that any deity is bad. ${ }^{6}$

Iphigenia firstly condemns Artemis for the logical - and moral ${ }^{7}$ - contradiction of her behaviour: on the one hand, she obliges Iphigenia to perform human sacrifices in Tauris, on the other, she bans from her own altars all those whose hands are bloodstained. However, Iphigenia then finds this thought intolerable, and resorts to believing that it is men who attribute unworthy qualities to the gods in order to justify their own crimes, while gods themselves cannot be evil. Therefore, she rejects both the claim that the human sacrifices performed in Tauris have been ordered by the goddess, and the tradition according to which Tantalus served the gods the flesh of his own son Pelops, so that the gods ate some of his body and consequently had to recompose it. ${ }^{8}$ According to Iphigenia, the gods cannot be bloodthirsty, whether in the past or in the present. By claiming that the gods must in every case think and behave according to human ethic criteria, Euripides contradicts Greek popular religion, which attributed to the gods human vices and virtues alike; ${ }^{9}$ thus, he expresses those "Enlightenment" ideas which Goethe was to appreciate and develop.

${ }^{5}$ Euripides's $I T$ is quoted according to J. Diggle's edition (Euripis Fabulae. Recognovit brevique adnotatione critica instruxit J. DiGGLE. Tomus II. Oxford 1981).

${ }^{6}$ Translations of IT are from M. Cropp's edition (Euripides, Iphigenia in Tauris. With Introduction, Translation and Commentary by M. J. CROPP. Warminster 2000).

${ }^{7}$ In Euripides and in Greek thought in general, intellectual terms can also have an ethic meaning. See CROPP (n. 6) 202 (ad Eur. IT 386). the gods.

${ }^{8}$ This story had already been rejected by Pindar (Ol. 1. 36-63), since it questioned the morality of

${ }^{9}$ K. J. DOVER reminds that it was a widespread belief that "there were some things which were hidden even from the gods", and that "the gods were not entirely anhamartêtos, an ambiguous word [...] that covers both freedom from intentional error and abstention from wrongdoing. Such a belief was firmly founded in the myths related in archaic and classical poetry, which portrayed the gods as subject to rage, spit and lust". Greek Popular Morality in the Time of Plato and Aristotle. Oxford 1974, 76. Euripides was not alone in criticizing the traditional view of the divine world, see CROPP (n. 6) 201 (ad IT 380-391). 


\section{LOVE BETWEEN SIBLINGS AND THE PHILOSOPHICAL-RELIGIOUS MESSAGE IN EURIPIDES'S IPHIGENIA TAURICA}

I shall now investigate how the religious issue is connected to the theme of family love in Euripides's Iphigenia Taurica. ${ }^{10}$

The premise lies in the fact that both humans and gods have familial bonds: namely, the human couple of siblings Orestes-Iphigenia corresponds to the divine couple of siblings Apollo-Artemis. The familial relationship between the two gods is specified in Orestes's account of the oracle which has ordered him to go to Tauris (IT 85-92):

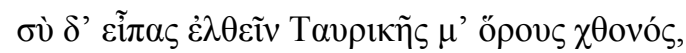

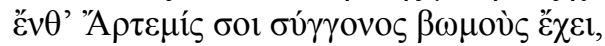

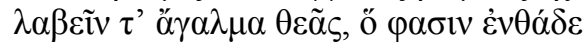

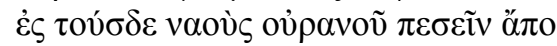

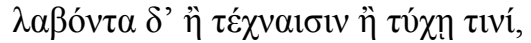

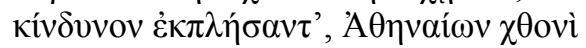

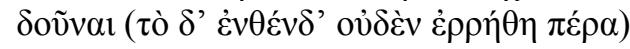

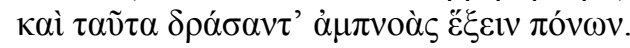

You said I must go to the borders of the Taurian land, where your sister Artemis possesses altars, and take the goddess's image which they say fell here into this temple from the sky - must take it by trickery or some sort of luck, and then when I have seen the peril through, must give it to the land of the Athenians (of what should follow from that, nothing was said), ${ }^{11}$ and after doing this would have respite from my ordeals.

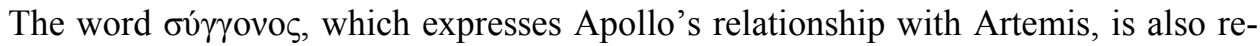
peatedly used with reference to Orestes and Iphigenia $(I T 149,231,795,805,851$, $856,870,990,1420,1448$ ).

Orestes and Iphigenia assume that Apollo and Artemis, being siblings, must show unity of purpose, or exhort them to. Thus, Orestes conjectures that, if Apollo has ordered the removal of the statue, Artemis must agree (IT 1012-1016), and Iphigenia prays Artemis to be favourable to the mission: otherwise, Iphigenia tells the goddess, «because of you the word of Loxias will no longer have truth for mortals» (IT 1084-

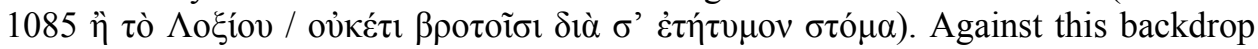
we can understand Iphigenia's last prayer to Artemis - which is also her last utterance in the play - in the moment of greatest danger: the Greeks have managed to

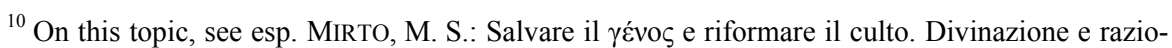
nalità nell'Ifigenia Taurica. MD 32 (1994) 55-98. On the importance of familiar love in Euripides's late tragedies, see Di BENEDETTO, V.: Euripide: teatro e società. Torino 1971, 311-319.

${ }^{11}$ Orestes's destiny after delivering the statue to Athens is revealed by Athena in the end (IT 1449 ff.). 
cheat the Taurians and set off, ${ }^{12}$ but immediately after they have exited the harbour a sudden storm pushes back their ship towards the shore (IT 1391-1397). Iphigenia surmises that the storm is due to Artemis's rage for the stealing of the statue (IT 1398-1402):

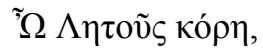

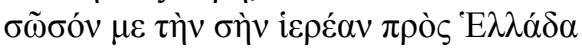

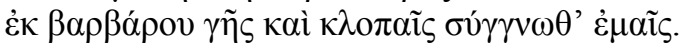

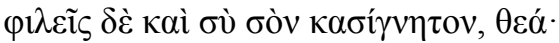

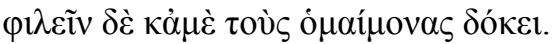

Iph. O daughter of Leto, rescue me, your priestess, back to Hellas from this barbarous land, and forgive my thieving. You too feel love for your own brother, goddess. You must expect that I shall love my kin.

In order to prompt the deity to rescue her and her brother, Iphigenia appeals to the value of love between siblings: she demands that the affection ( $\varphi$ i $\lambda i \alpha)$ which unites Artemis to Apollo induce the goddess to favour her, who is acting in accordance with that same principle. This can be the occasion for Artemis to demonstrate that she corresponds to the purified image of the Gods which Iphigenia has drawn in her solilo-

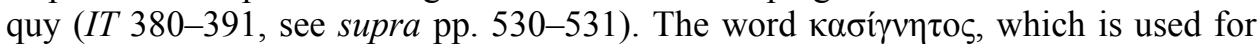
the siblings Artemis and Apollo, occurs five times with regard to Orestes and Iphigenia $(158,792,983,1074,1473)$.

But does the goddess meet Iphigenia's expectations? The human siblings are in fact rescued by divine intervention, though not by Artemis, but by Athena. She arrests king Thoas's pursuit of the Greeks, and explains that Orestes has come in Tauris following Apollo's oracle that prescribed him to move Artemis's statue to Athens in order to put an end to the persecution of the Erinyes (IT 1435-1445). She then assigns to Orestes and Iphigenia the task of founding new cults in Attica in honour of Artemis, in order to compensate for the loss of the cult in Tauris (IT 1446-1467). She orders Thoas to let the women of the chorus sail to Greece (IT 1467-1469) and reminds Orestes that she has already saved him once, on the Areopagus hill in Athens (IT 1469-1474). This latter specification reveals the model with which Euripides confronts himself: Aeschylus's Eumenides. ${ }^{13}$

Praising the reaction of Thoas, who declares that he will follow the divine orders (IT 1475-1485), Athena points out that Necessity ( ò $\chi \rho \varepsilon \omega ́ v)$ reigns not only over men, but also over gods (IT 1486).

\footnotetext{
${ }^{12}$ Iphigenia has told the Taurian king Thoas that the two Greeks who have been captured (Orestes and Pylades) are contaminated by matricide, and that they have contaminated the statue too by touching it. Therefore, both the Greeks and the statue must be brought to the sea shore and purified by sea water, before human sacrifice can be performed (IT 1157-1202). Thus the three Greeks can reach their ship and put out to sea.

${ }^{13}$ The connections between IT and the whole Oresteia have been investigated esp. by CALDWELL, R.: Tragedy Romanticized: the Iphigenia Taurica. CJ 70 (1974-1975) 23-40.
} 
Critics have wondered why it is Athena who appears in place of a deity more involved in the previous events concerning the Atreidae family: Apollo or Artemis. ${ }^{14}$ Especially Artemis has been at the centre of a confrontation between two different images of divinity. One could expect that the goddess herself would appear and express her approval of Iphigenia's purification of her image from the cruelty which the Taurians have attributed to her; however, this does not happen, and we do not hear directly Artemis's voice. This strengthens the impression that the goddess is not able to "redeem herself" from her barbarian nature; nor can the human Iphigenia alone redeem her. As Mastronarde remarked: ${ }^{15}$

"Despite the details in the play that tend to focalize the bloodthirsty aspect of Artemis as Taurian and unGreek, this aspect is not merely a projection of barbarian belief: the goddess Artemis is in need of rescue from herself by her brother and in need of the civilizing influence of Athena and Athens."

Apollo wants to rescue his sister Artemis from the Taurian barbarity through Orestes's mission; Orestes, after recognizing his sister Iphigenia, plans to free and bring her back to Greece with him. Therefore, he has the double task of saving both the divine and the human sister. However, in order to accomplish this task he needs the help of Athena. Through her intervention, Artemis's rescue turns into a celebration of Athens, the city where the goddess is going to replace the bloodthirsty rites of Tauris with new civilized cults, ${ }^{16}$ and where the troubles of the Atreidai family will be finally solved. Not only will Orestes not be persecuted by the Erinyes any longer - as already achieved at the end of Aeschylus's Eumenides - but even Iphigenia, whom everybody believes dead, will return to the Greeks. In the end, the spectators learn that she will live in Attica as a priestess in the Artemis temple of Brauron (14621467).

Therefore, Athena's appearance is justified both by the fact that she has already saved Orestes in Athens, and by her being the goddess of Athens. ${ }^{17}$

${ }^{14}$ See $e . g$. P. KYRIAKOU: "[Athena's] appearance is unexpected and her speech does not settle all issues raised in the play. [...] The divine agents that have caused distant and more recent events [scil. Apollo and Artemis] fail to appear, explain their actions and provide guidance to their believers. This failure does not imply that the siblings gods do not condone the actions of the mortals but it indicates clearly that they remain aloof from, and paradoxically least involved in, these actions." A Commentary on Euripides 'Iphigenia in Tauris by P. KYRIAKOU. Berlin - New York 2006, 450-451.

${ }_{15}$ Mastronarde, D. J.: The Art of Euripides: Dramatic Technique and Social Context. Cambridge $2010,165$.

${ }^{16}$ The memory of human sacrifice will be kept in the new rites, as during festivals a priest will hold a sword against the throat of a man and draw some blood (1458-1461).

${ }^{17}$ The reason why precisely Athena appears at the end of $I T$ is seen by CALDWELL (n. 13) 28: Orestes's "desperate plight and final reprieve in the IT replicate the events of the Eumenides", and therefore "it is completely appropriate that Athena should once again appear to rescue him". Moreover, K. Lange understands that Athena's presence is also due to the reminiscence of Homer's Odyssey: the goddess protects Orestes from Poseidon's wrath, as she protected Odysseus ("Poseidon ,verfolgt" einmal die Flüchtigen wie er es in der Odyssee mit Odysseus permanent tut; Athene dagegen [als dea ex machina] beschützt sie, und Poseidon fügt sich dem Willen der Göttin"; LANGE, K.: Euripides und Homer: Untersuchungen zur Homernachwirkung in Elektra, Iphigenia im Taurerland, Helena, Orestes und Kyklops. Stuttgart 2002, 103). 
Athena's final speech contains a reference to the theme of affection between siblings (IT 1487-1489):

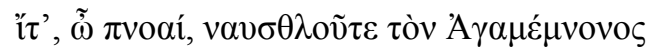

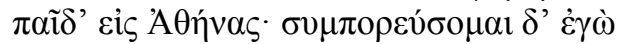

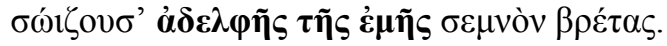

Ath. Go, winds, give passage for Agamemnon's son to Athens. I shall go with you and keep my sister's holy image safe.

Athena's kinship with Artemis is another element which justifies her appearance and her concern about the success of the expedition. These words suggest that the gods do share with men the value of familial love; Athena has also previously revealed

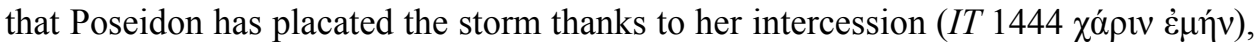
suggesting the idea that the gods are part of a family where all members care about one another's desires. ${ }^{18}$ This can be considered as the "positive" element in a conclusion which gives the impression of hardly reconciling the divine and the human worlds. ${ }^{19}$ M. S. Mirto has written ${ }^{20}$ very illuminating words on this:

"Molti segnali additano una linea di comportamento che, per Ifigenia ed Oreste, si è comunque rivelata positiva: il coraggio della virtù - che di volta in volta può assumere l'aspetto di philia fraterna, spirito di autosacrificio per il bene familiare, amor di patria, rispetto degli ospiti o venerazione degli dei e attenta considerazione dei loro segnali - e, in seconda istanza, l'uso della virtù come chiave di lettura della volontà divina e del suo operato."

(Many signals indicate a pattern of behaviour which, for Iphigenia and Orestes, has turned out to be positive: the courage of virtue - which from time to time can assume the aspect of fraternal love, spirit of self-sacrifice for the sake of the family, ${ }^{21}$ patriotism, respect for one's

${ }^{18}$ A. P. BURNETT writes that Euripides "has chosen to depict the residents of heaven as members of a noble and well regulated family, respectful of law, interested in morality and cognizant of one another's plan". Catastrophe Survived: Euripides' Plays of Mixed Reversal. Oxford 1971, 66-67. I believe that, instead of a "noble" family, Euripides depicts a family bound by less formal and more sincere relationships of affection.

19 An example of the sense of "dissatisfaction" which the Euripidean end leaves in several readers is in Wright, M.: Euripides' Escape-Tragedies: A Study of Helen, Andromeda, and Iphigenia among the Taurians. Oxford 2005, 381-382: "the gods'words do not reveal all that we might wish to know. Far from it: the characters and audience find out who is responsible for their sufferings, and they are given access to a partial hierarchy of the supernatural powers: but that is all. If we were expecting something more profound than that - moral justification of what has happened, or some sign that the gods care about human life - we will be grievously disappointed. This absence of intellectual or spiritual meaning is the main reason why $[. .$.$] the institution of ritual cannot be seen as a straightforwardly positive form of closure. In$ the place of theological profundity, the plays end on a note of emptiness." However, Wright tends to underestimate the positive elements of the conclusion.

${ }^{20}$ MiRTO (n. 10) 96.

${ }^{21}$ In IT 999-1006, Iphigenia has declared that she will do her best to secure her brother's salvation, even in case this means her own death. 
hosts, ${ }^{22}$ or worship of the gods and attentive understanding of their signals - and, secondly, the usage of virtue as a means to interpret divine will and actions.) $)^{23}$

Familial affection is part of that "virtue" which the human protagonists display. It is valued both in the human and in the celestial worlds, and therefore is the basis for a new possible "dialogue" between the two.

\section{THE "INACCEPTABLE” ELEMENTS OF THE EURIPIDEAN PLOT}

In re-working Euripides's Iphigenia taurica, Goethe strove to further strengthen the connection between the human and the divine worlds. His understanding of religion was rooted in the Enlightenment idea of a Supreme Being who acted in full accordance with the principles of human morality. ${ }^{24}$ But Enlightenment thinking was not the only source of inspiration for Goethe: he was also deeply influenced by the religious movement of Pietismus, which argued that God had posed his Revelation in the heart of every human being. ${ }^{25}$

The combined influence of the Enlightenment and pietismus suggests which elements of the Euripidean plot were not acceptable for Goethe: first, uncertainty in communication between men and gods. Until the end of the play, when the humans hear the voice of the divinity directly, the only means of communication are dreams and oracles, both characterized by obscurity. As a matter of fact, at the beginning of the Euripidean play Iphigenia misinterprets the dream which foreshadows that Orestes is going to be brought to her to be sacrificed, interpreting it as an announcement of Orestes's death (IT 42-62). Her misinterpretation demonstrates both the lack of human understanding and the obscurity of the divine messages. ${ }^{26}$ As we shall see, Goethe was concerned with the problem of establishing a more direct "communication channel" between mortals and immortals, but without allowing for the direct divine appearance among the humans.

Deception and theft at the expenses of the Taurians were equally inacceptable. In Euripides, cunning against barbarians does not arouse any scruples, as a demonstration of Greek superiority over an inferior civilization. On the contrary, theft is a problematic act, because it involves not only the Taurians, but also Artemis, who may

${ }^{22}$ In IT 1020-1023, Iphigenia refuses to kill Thoas because he is her host.

${ }^{23}$ Translation is mine.

${ }^{24}$ On the connections between Goethe's ideas on religion and the Enlightenment, see especially RASCH, W.: Goethes, Iphigenie auf Tauris ' als Drama der Autonomie. München 1979.

${ }^{25}$ Pietism played an important role in Goethe's education. See CHIARLONI, A. Goethe und der Pietismus. Erinnerung und Verdrängung. Goethe-Jahrbuch 106 (1989) 133-59; SCHNEIDER, U.-M.: Propheten der Goethezeit: Sprache, Literatur und Wirkung des Inspirierten. Göttingen 1995.

${ }^{26}$ As Caroline P. Trieschnigg writes, the dream's "complexity and obscurity make the audience experience the difficulties of interpretation, which relates to one of the main themes of the play, namely the human limitations in understanding the divine" (Iphigenia's dream in Euripides' Iphigenia Taurica. $C Q 8$ [2008] 461-478; 463). 
not want her statue to leave Tauris; therefore, Iphigenia asks for Artemis's forgiveness

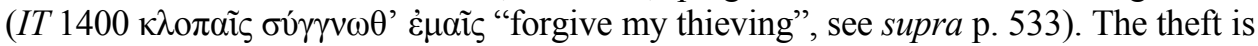
a merely cultic problem, and on a cultic level is resolved: Athena compensates for the Taurian ceremonies by granting Artemis new ceremonies in Attica (whereas the Taurians are provided with no compensation). In fact, the theft is justified by the necessity of providing Artemis with more civilized cults than the one performed in Tauris.

In Goethe's tragedy, theft becomes a crime against other human beings, as the Taurians are. In a period in which the equality of men and the universality of morality were proclaimed, ${ }^{27}$ cunning and theft against other men, though barbarians, could no more be admitted. Iphigenie hates deceiving the Taurians, who are Menschen "men" (1524-1526), and feel ashamed for the double sin of deceiving and robbing Thoas. The king, in his turn, denounces that this would be but the latest of a series of plunders which Greek greed has committed in barbarian countries (2102-2106). Thus, the same act which demonstrated the superiority of the Greeks now demonstrates that they cannot be considered morally better than the barbarians.

The most unbearable element of the Euripidean finale is perhaps the limitations which the gods and Fate pose to human freedom and autonomy of action. It is a fact that, without Athena's intervention, the Greeks would fail to escape from Tauris; the goddess not only saves them, but also determines their future destinies. The conclusion that Necessity rules over men and gods alike lowers the curtains on a tragedy where the humans seem only passive pawns in a play determined by the confrontation of supernatural forces. This conclusion is incompatible with the eighteenth-century notion of human autonomy, as summarized by Rasch: ${ }^{28}$

“[s]ie bedeutet, daß der Mensch nach seinem Bewußtsein nicht den Willen Gottes oder eines weltlichen Herrschers in seinem Handeln und Verhalten vollzieht, sondern seinen eigenen Willen, in eigener Entscheidung und Verantwortung. Autonomie bedeutet, Gesetze und Pflichten aus eigener Einsicht und freier Bejahung zu erfüllen, ohne daß diese Erfüllung von äußeren Gewalten erzwungen wird."

(It [scil. Human autonomy] means that man, in accordance with his conscience, in his actions and behaviour does not fulfil the will of God or of an earthly master; instead, he fulfils his own will, taking his/her own decisions and responsibilities. Autonomy means fulfilling a duty on the basis of a full understanding and free consent, without being forced by exterior powers. $)^{29}$

In Goethe's view, whatever positive elements the Euripidean ending may contain, they could not compensate for the thwarting of human autonomy. In his play, it is

${ }^{27}$ See RASCH (n. 24) 26-29.

${ }^{28}$ RASCH (n. 24) 32. Rasch argues that Iphigenie can be considered a Selbsthelfer, a person who is able to determine her fate autonomously, by means of her own strengths. However, THOMAS BERGER has corrected this view, by pointing out that Iphigenie does not solve the dramatic situation by herself, but by collaborating with Orestes and Thoas (Der Humanitätsgedanke in der Literatur der deutschen Spätaufklärung. Heidelberg 2008, 199). The concept of human autonomy from the divine agency is still valid: it does not relate to a single man's solitary action, but to the common action of the community.

${ }^{29}$ Translation is mine. 
Thoas and Pylades who mention the bonds of Necessity: on the one hand, the Taurian king tells Iphigenie that Fate obliges her to perform human sacrifices (259); on the other, Pylades believes it necessary to deceive Thoas in order to achieve salvation (1645). Both characters fail to understand that what they call Necessity is in fact their inability to evade the ancient rules and adopt a new conception of the divine, as well as of human duties and relationships: by voicing this new conception, Iphigenie will demonstrate - as we shall see - that men can determine their own fate.

\section{LOVE BETWEEN SIBLINGS AND THE PHILOSOPHICAL-RELIGIOUS MESSAGE IN GOETHE'S IPHIGENIE AUF TAURIS}

The motif of familiar love has a prominent place in this struggle for human self-determination of Goethe's Iphigenie. This centrality can be explained with the pietistic emphasis on the spontaneity of the most genuine human feelings, such as love and affection, regarded as the foundation of an authentic religious sensibility. From these premises, it is not surprising that Goethe appreciated and developed not only the intellectualistic reflection of the Euripidean Iphigenia on the ethical qualities of the gods, but also her appeal to the value of philia, of love and affection. In fact, this "sentimental" side of the character becomes prominent, as Goethe's Iphigenie asserts "I do not reason, I only feel" (1650 Ich untersuche nicht, ich fühle nur). The appeal to sentiment is the weapon which Iphigenie successfully employs to solve the tragic predicament, and the value of familiar love is at the core of this interior force.

The power of the affection between the two siblings is proved by Orestes' madness being cured before his departure from Tauris, not by Artemis's statue, but through his sister's love. In Euripides's play, Orestes suffers a fit of madness when he is discovered and caught with Pylades by the Taurian herdsmen (IT 281-291); ${ }^{30}$ and yet, his fit soon ends and he is no more affected by the illness. Goethe expands Orestes's hallucinations so as to enhance Iphigenie's healing powers. She first addresses a prayer to the divine siblings, and especially Artemis (1317-1331):

Geschwister, die ihr an dem weiten Himmel

Das schöne Licht bei Tag und Nacht herauf

Den Menschen bringet, und den Abgeschiednen

Nicht leuchten dürfet, rettet uns Geschwister!

Du liebst, Diane, deinen holden Bruder

Vor allem, was dir Erd' und Himmel bietet,

Und wendest dein jungfräulich Angesicht

Nach seinem ew'gen Lichte sehnend still.

O laß den einz'gen Spätgefundnen mir

Nicht in der Finsterniß des Wahnsinns rasen!

\footnotetext{
${ }^{30}$ For a valuable treatment of madness in Euripides, see BOND, GODFREY W.: Euripides Heracles. Oxford 1988, on HF 830-1009.
} 
Und ist dein Wille, da du hier mich bargst, Nunmehr vollendet, willst du mir durch ihn Und ihm durch mich die sel'ge Hülfe geben; So lös' ihn von den Banden jenes Fluchs, Daß nicht die theure Zeit der Rettung schwinde.

Celestial pair, who from the realms above / By night and day shed down the beauteous light / To cheer mankind, but who may not illume / departed spirits, save a mortal pair! / A brother's and a sister's anguish pity! / For thou, Diana, lov'st thy gentle brother / Beyond what earth and heaven can offer thee / and dost, with quiet yearning, ever turn / Thy virgin face to his eternal light. / Let not my only brother, found so late, / Rave in the darkness of insanity! / And is thy will, when thou didst here conceal me, / At length fulfill'd - would'st thou to me through him, / To him through me, thy gracious aid extend, - Oh, free him from the fetters oof this curse, / Lest vainly pass the precious hours of safety. ${ }^{31}$

The prayer is clearly reminiscent of the one pronounced by the Euripidean Iphigenia (1398-1402, see supra p. 533). Iphigenie tries to arouse empathy in Artemis by the same "strategy" used by the Euripidean heroine, an appeal to the affection between siblings. However, it is noteworthy that the Goethean Iphigenia does not ask for a direct intervention of a deity; instead, she begs the goddess to accord her salvation through Orestes, and to Orestes salvation through her (1328-1329). The deity should not act directly, but through the medium of the two human siblings.

Iphigenia's prayer is heard, as a few lines later Orestes proclaims that the curse of the Erinyes is vanishing (1358 Es löset sich der Fluch, mir sagt's das Herz) and Pylades confirms it (1536). In the end, Orestes recognizes that it is Iphigenie who has cured him (see infra p. 543).

Even though Orestes has already been healed, the three friends carry on the mission of stealing the statue from Artemis's temple, prompted by Pylades. Unlike in the ancient model, it is he and not Iphigenie who conceives the escape plan, whereas the woman must act as executor. However, in three consecutive soliloquies (1369-1420, 1503-1531, 1689-1766) she gives voice to her own interior rebellion against the idea of deceiving Thoas and robbing him of the statue. It is not by chance that Goethe makes extensive use of the soliloquy, which Euripides too had employed to cast Iphigenia's reflections on the goodness of Artemis in the above-quoted lines 380-391. The morality of the gods is the issue at stake in the Euripidean as well as in the Goethean play.

Iphigenie again asks the gods to save her (1716-1717): rettet mich, / rettet euer Bild in meiner Seele! In the Greek play, salvation ( $\sigma \omega \tau \eta \rho i ́ \alpha)$ always meant escaping

\footnotetext{
${ }^{31}$ Translations from Goethe's Iphigenie are from Collected Works of Johann Wolfgang von Goethe. Hastings 2013 (Translator Anna Swanwick).
} 
from Tauris; but here she intends it as salvation from the necessity of stealing: she begs the gods to give her an alternative means of escape. Beside the exterior Bild, Artemis's cult image, another interior image of the gods is preserved in her soul, and this image is incompatible with the idea that the gods have ordered a theft. While the oracle prescribes to "save" Artemis's statue from Tauris, Iphigenie begs the Gods to save her inner image of the Gods themselves which would be destroyed by such immoral acts as cunning and thieving.

Unable to keep to the theft plan, Goethe's Iphigenie decides to reveal Thoas the truth and begs him to let the Greeks go in the name of human compassion. From a structural point of view, her decision has the same function as the storm which, in Euripides's IT, thwarts the success of the human escape: but this analogy should not hide their deep difference. Euripides's play involves the agency of an 'obstacle' which is totally out of human control that can only be removed by supernatural power: the deus ex machina is unavoidable. In Goethe's tragedy, on the contrary, it is stressed that the winds are favourable to navigation (1158-1159): no external obstacle prevents the deception plan from being successful, which instead is hindered by an interior moral scruple. Therefore, the tragic predicament is now solved at a human level, without divine interference: it is only Thoas's decision which will determine the outcome of the situation. Iphigenie knows that, if he refuses to let the Greeks leave, no other human means can save her and her dears: she would be forced to ask for divine help (1884): Ruf' ich die Göttin um ein Wunder an?. This anguished question voices Iphigenie's possible need of having to appeal to divine intervention, pre-

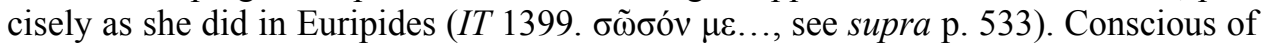
this danger, before revealing the truth to the king once again Iphigenie addresses the gods in what sounds, more than a prayer, a challenge (1916-1919):

\section{Allein Euch leg' ich's auf die Kniee! Wenn Ihr wahrhaft seid, ${ }^{32}$ wie ihr gepriesen werdet; \\ So zeigt's durch euern Beistand und verherrlicht \\ Durch mich die Wahrheit!}

Thus on my knees I supplicate the gods. / Oh, are you truthful, as men say ye are, / Now prove it by your countenance and aid; Honour the truth through me! ${ }^{33}$

Iphigenie does not invoke the gods' appearance, but asks that they show their power through her. ${ }^{34}$ By using, in the previously quoted line 1884, the word Wunder, Goethe draws an analogy between the Greek deus ex machina and the Christian concept of

${ }^{32}$ In the prose version of 1779 , Goethe wrote wenn ihr die wahrhaftigen seyd "if you are the truthful ones", but in the final version of 1787 he uses the word wahrhaft, which can be read both as an adjective ("if you are truthful") and as an adverb ("if you really are/exist"). For Iphigenia, gods cannot exist if they are not truthful.

${ }^{33}$ My changes to the translation are in italics.

${ }^{34}$ I cannot agree with BERGER (n. 28) 194, when he says that Iphigenia hopes for a direct intervention of the gods to save the situation. Instead, she hopes that the gods can give her the power to persuade Thoas to let her and her dears leave Tauris. 
miracle: the final intervention of a deity like Athena would be comparable to a miracle, but in the Goethean play this is not necessary, for the humans will succeed autonomously. They will offer a demonstration of what Goethe would write in Die natürliche Tochter $(5,8)$ :

\title{
Wenn ein Wunder auf der Welt geschieht, Geschieht's durch liebevolle, treue Herzen.
}

If ever a miracle has happened in the world, it has happened through loving, faithful hearts. ${ }^{35}$

It is exactly Iphigenie's purity of heart ${ }^{36}$ which has allowed her to heal Orestes, setting an example of a new type of miracle, performed not by the divine sister, but by the human one. An analogous concept of miracle is expressed by Lessing's Nathan: ${ }^{37}$ while his adoptive daughter Recha believes that an angel has saved her from the fire which destroyed their house, Nathan replies that it is a Templar who has rescued her; nonetheless a miracle has happened (213-219):

\author{
Wie? Weil \\ Es ganz natürlich, ganz alltäglich klänge, \\ Wenn dich ein eigentnlicher Tempelherr \\ Gerettet hätte: sollt' es darum weniger \\ Ein Wunder seyn? - Der Wunder höchstes ist, \\ Daß uns die wahren, echten Wunder so \\ Alltäglich werden können, werden sollen.
}

${ }^{35}$ Translations from Die natürliche Tochter and Lessing's Nathan the Wise are mine.

${ }^{36}$ The Goethean concept of heart has more than one source of inspiration. R. NUTT-KOFOTH points out that the Goethean Herz combines the two spheres which in the Empfindsamkeit (Sentimentalism) were expressed by the words Herz and Seele: Herz as seat of the emotions, Seele as ethical core (Weimarer Klassik und Empfindsamkeit: Aspekte einer Beziehung. In Gefühlskultur in der bürgerlichen Aufklärung. Ed. A. AURNHAMMER. Tübingen 2004, 255-270, esp. 261-262). The Goethe-Wörterbuch explains that Goethe was deeply influenced by Herder's understanding of the heart as seat of both the emotional and the spiritual powers of the individual (Herz in Goethe-Wörterbuch. Hrsg. von der Berlin-Brandenburgischen Akademie der Wissenschaften. Bd. 4. Stuttgart 2004, 1079). Goethe revalorized the religious role of Herz as seat of the spontaneous perception of God and morality, against Kant, who claimed that neither truth nor the divine could be accessed via feelings (see KRIMMER, E.: "Then Say What Your Religion Is": Goethe, Religion, and Faust. In Religion, Reason and Culture in the Age of Goethe. Ed. E. KRIMMER - P. A. SIMPSON. Rochester, NY 2013, 99-119, esp. 106-107). The literature on Herz in Schiller highlights its importance for the religious movement of Pietism: the heart was elected, against reason, the organ which unterstood the divine truth (see LöHNE, K.: Max Piccolomini und die Ethik des Herzens. Acta Germanica 11 [1979] 97-112, esp. 104; LohmanN, K.: Die Bedeutungssphäre des Wortes „Herz “ im dramatischen und philosophischen Werkes Friedrichs Schillers. Diss. Münster 1959, 6). Goethe's Iphigenie proves to be near to the pietistic radicalism in saying that she only relies on sentiment (1650).

${ }^{37}$ Lessing expressed his opinion on miracles also in Über den Beweis des Geistes und der Kraft (1777): see YASUKATA, T.: Lessing's Philosophy of Religion and the German Enlightenment: Lessing on Christianity and Reason. Oxford 2002, 57-60. Lessing's point is that it is impossible to believe in miracles which are reported in written sources, but only in miracles which one sees with his/her own eyes. On the Eighteenth-century controversy on miracles, see BROWN, C.: Issues in the history of the debates on miracles. In The Cambridge Companion on Miracles. Ed. G. H. TwelfTREE. Cambridge 2011, 277-283. 
What? Because it would sound totally natural, an everyday event, if a real Templar had rescued you: for that reason should it be any less a miracle? The supreme miracle is that for us the real, genuine miracle can happen in everyday life, should happen in everyday life.

Goethe's Iphigenie shows how the Wunder can occur in daily life; it is sufficient that men hear the voice of humanity, which speaks to every heart, regardless of one's country, provided that the heart itself is pure (1939-1941):

Es hört sie jeder,

Geboren unter jedem Himmel, dem

Des Lebens Quelle durch den Busen rein

Und ungehindert fließt.

'Tis [scil. The voice of humanity and truth] heard by all, / Whate'er may be their clime, within whose breast / Flows pure and free the gushing stream of life.

However, despite her powerful appeal to humanity, Iphigenie alone cannot achieve salvation. Thoas seems at first moved by her words (1986 wie oft besänftigte mich diese Stimme) but then he rejects her request (2099-2101): he may let the Greeks go, but he will not let them steal the statue. On the one hand, Iphigenie demands from Thoas an act of humanity, on the other hand, the Greeks still want to commit such an inhuman act as stealing. The heroine cannot solve this contradiction; instead, it is Orestes who removes the obstacle of theft, by reinterpreting Apollo's oracle (21112117):

Um Rath und um Befreiung bat ich ihn

Von dem Geleit der Furien; er sprach:

„,Bringst du die Schwester, die an Tauris Ufer

Im Heiligthume wider Willen bleibt,

Nach Griechenland, so löset sich der Fluch. “

Wir legten's von Apollens Schwester aus,

Und er gedachte dich!

His [scil. Apollo's] counsel I implor'd, / To free me from the Furies' grisly band. / He answer'd, "Back to Greece the sister bring, / Who in the sanctuary on Tauris' shore / Unwillingly abides; so ends the curse!". / To Phoebus' sister we applied the words, / And he referred to thee!

Orestes's reinterpretation of the oracle paves the way for the happy ending, like the deus ex machina in Euripides's play. ${ }^{38}$ More precisely, the positive solution is elicited both by Iphigenie's "moral suasion" and by Orestes's intervention; what Iphigenie

\footnotetext{
${ }^{38}$ BERGER (n. 28) 196 correctly explains the suddenness of Orestes's reinterpretation as derived from the suddenness of the deus ex machina.
} 
foresaw in her prayer to the divine siblings (1328, see supra p. 539) eventually takes place: the two human siblings save each other. Goethe has given Orestes a more prominent role in the salvation of the Greeks than Euripides, who instead emphasizes female agency first through Iphigenie's plan, then through Athena's appearance. ${ }^{39}$

Orestes's reinterpretation is based on the ambiguity of the word Schwester, which may refer both to Apollos' sister (cf. 563-568, 610-612, 721-727), as Orestes and Pylades interpret it, and to Orestes' own sister. Thus, Goethe does away with the oracle's ambiguity which, in Euripides, revealed to Orestes only part of the mission's aim, leaving it to Athena to finally disclose to him that he had come to Tauris in order to rescue both the statue and his own sister (1438-1441b). In the modern play, the oracle does not pass over silence that he will rescue his own sister; on the contrary, it makes it the only reason for Orestes's presence in Tauris. In his final speech, Orestes recognizes that Iphigenie has been his saviour (2117-2126):

Die strengen Bande

Sind nun gelös't; du bist den Deinen wieder,

Du Heilige, geschenkt. Von dir berührt,

War ich geheilt; in deinen Armen faßte

Das Übel mich mit allen seinen Klauen

Zum letztenmal und schüttelte das Mark

Entsetzlich mir zusammen; dann entfloh's

Wie eine Schlange zu der Höhle. Neu

Genieß ich nun durch dich das weite Licht

Des Tages. Schön und herrlich zeigt sich mir

Der Göttin Rath. Gleich einem heil'gen Bilde,

Daran der Stadt unwandelbar Geschick

Durch ein geheimes Götterwort gebannt ist,

Nahm sie dich weg, dich Schützerin des Hauses;

Bewahrte dich in einer heil'gen Stille

Zum Segen deines Bruders und der Deinen.

Da alle Rettung auf der weiten Erde

Verloren schien, gibst du uns alles wieder.

Or. The bonds severe, / Which held thee from us, holy one, are rent, / And tou art ours once more. At thy blest touch, / I felt myself restor'd. Within thine arms, / Madness once more around me coil'd its folds, / Crushing the marrow in my frame, and then / For

${ }^{39}$ Cf. BARBERA, S.: Goethe e il disordine: una filosofia dell 'immaginazione. Venice 1990, 127: "Che sia Oreste, e non Ifigenia, a risolvere l'oracolo, ci indica lo stato di simbiosi raggiunta tra la sfera maschile e quella femminile, l'atteggiamento attivo e quello paziente, nell'ambito della verità." ("The fact that not Iphigenia, but Orestes solves the oracle, reveals the symbiosis which the female and the male sphere, the active and the passive behaviour, have reached in the field of truth"; translation is mine). Barbera points out both that Iphigenia has "converted" Orestes - who wanted to resort to violence - to the truth of human solidarity and sincerity, and that the newly converted Orestes becomes able to play an active role in this sense. 
ever, like a serpent, fled to hell. Through thee, the daylight gladden me anew. / The counsel of the Goddess now shines forth / In all its beauty and beneficence. / Like to a sacred image, unto which / An oracle immutably hath bound / A city's welfare, thee Diana took, / Protectress of our house, and guarded here / Within this holy stillness, to become / A blessing to thy brother and thy race. / Now when each passage to escape seems clos'd, and safety hopeless, thou dost give us all.

Orestes's words confirm that he has already been healed before his departure from Tauris through his sister (2125 durch dich). Iphigenie is described in ways more remindful of Christian than pagan religion: Orestes addresses her with the epithet Heilige and says that she has healed him by simply touching him, as if she were a saint with thaumaturgical powers. ${ }^{40}$ As a holy relic protects a city, Iphigenie has protected her own family. Moreover, the hyperbole alle Rettung auf der witen Erde seems to turn her into a Christological figure. Through this comparison of Iphigenie with a holy relic the process of the substitution of the cult statue with her is completed.

Orestes's reinterpretation of the oracle makes it possible for Thoas to allow the departure of the Greeks. In her final speech to the king, Iphigenie expresses her affection towards him (2155-2157):

\section{Werth und theuer, \\ Wie mir mein Vater war, so bist du's mir, Und dieser Eindruck bleibt in meiner Seele.}

Honour'd and belov'd / As mine own father was, art thou by me: / And this impression in my soul remains.

Iphigenie has already said that Thoas has been her second father, and this made the thought of cheating and robbing him even more hateful (1641-1642, cf. 2002). Thoas's paternal role is an expansion of the circle of familial affection, which now includes even a barbarian, with the result that the distance between Greeks and nonGreeks is completely cancelled. Iphigenie gratifies Thoas with the appellation of father in order to exhort him to give her and her brother his blessing before they sail: she desires that strong bonds of hospitality be established between the Taurians and the Greeks, so that the geographical distance is compensated for by their spiritual proximity (2153-2155). The paternal characterization of Thoas develops in familial terms the relation of hospitality which united Thoas and Iphigenia in Euripides's play, and which induced Iphigenia to disapprove of Orestes's advice to kill the stranger

${ }^{40}$ The Christian symbology in the Iphigenie is investigated by TORRANCE, I.: Religion and Gender in Goethe's Iphigenie auf Tauris. Helios 34 (2007) 177-206, esp. 184-185. Torrace points out that Thoas's herald Arkas, by calling Iphigenia Heil'ge Jungfrau (holy virgin) associates her with virgin Mary. The scholar adds that "[t]his terminology contributes to Iphigenia's portrayal as a divine healing force: «heilig» (holy) and «heilen» (to heal) are cognates in German. The image of evil that flees like a serpent to its lair is biblical (cf. e.g. Revelation 12:9, 20:2; Genesis 3)." 
(IT 1020-1023). In Goethe's play, the concept itself of stranger is eliminated: the value of family love unites not only men and gods, but also all human beings.

\section{CONCLUSIONS}

In the light of what was observed above, it can be safely argued that Goethe understood that in Euripides's play the value of affection between siblings functioned as a "communication channel" between the human and the divine worlds, a channel which - from his point of view - could be further enhanced. While the course of action in Euripides's plot forces Iphigenia to ask the goddess to show that she approves of and shares that value by directly intervening, in Goethe the divine sister transfers her powers to the human sister. In the Euripidean play, the thaumaturgical powers of the goddess were concentrated in her cult statue. In Goethe those powers move from the material to the immaterial image of the goddess which is conserved in Iphigenie's soul. This transfer makes the happy ending possible, as Orestes has no more need to steal the statue to be freed from the persecution of the Erinyes: the removal of the theft plot allows for an agreement between Orestes and Thoas to be signed; salvation is achieved through purely human means, without divine intervention (a deus ex machina or, in Christian terms, a miracle). The appearance of the deity is replaced by the collaboration between three human beings: Iphigenie, who first heals Orestes, then shows the necessity of human compassion to Thoas; her brother Orestes, who understands the correct content of the oracle; and Thoas, whom Iphigenia includes in the sphere of family by calling him "father". Not only do the two siblings demonstrate the power of their mutual affection, but Iphigenie is also able to expand the circle of family, to include potentially each man.

The fact that Iphigenie receives divine powers does not turn her into a supernatural figure: on the contrary, she heals Orestes thanks to her outstanding human qualities, condensed in the image of the purity of the heart; and it is by appealing to human solidarity that she persuades Thoas. This is not a contradiction, but the realisation on stage of the concept of humanity as expressed by Johann Gottfried Herder: "das Göttliche in unserm Geschlecht ist also Bildung zur Humanität". 41 The "most divine" and the "most human" elements coincide in man.

Iphigenie is not an exception, a privileged human being; the transfer of Artemis' powers to her is paradigmatic of the presence of divine power in every human being, regardless of his/her nationality. In fact, Iphigenie promises Thoas that she will welcome every Taurians who will arrive in Greece as if he were a god (2162 Empfangen will ich ihn wie einen Gott). The Christological images highlight the role of Iphigenie and the universality of her message: like Christ, she has sent a message of salvation

41 "The divine element in our race is thus the cultivation of humanity". HERDER, J. G.: Briefe auf Beförderung der Humanität. Brief 27. In Werke in zwei Bänden. Ed. H. D. IRMSCHER. Frankfurt a. M. 1991, 147-148. 
which is directed to every human being; the salvation of one family, the Atreidae, paves the way for the salvation of humanity.

The fact that the Gods speak directly to the human heart does away with the ancient obscure forms of communication between the supernatural and the natural worlds. In order to understand the divine will, the humans must not try to interpret such obscure signs as oracles or dreams; instead, they must find the answer by questioning themselves. ${ }^{42}$ If they can hear the interior voice of humanity, they can be sure that this voice coincides with the divine voice.

Without underestimating Goethe's changes to the ancient model, we must point out that the intellectual and ethic premises of his Iphigenie are already present in the Euripidean Iphigenia. Both protagonists are characterized by their moral autonomy from myth, and their firm belief that the gods correspond to the image they have of them, even though this belief contradicts myth; that myth which is not a corpus of remote stories, but their own past and present. How can the Euripidean Iphigenia deny that Artemis relishes in human blood, when Artemis herself has installed her in Tauris, charged with human sacrifices? How can the Goethean Iphigenie refuse to cheat the Taurians, if this is, in myth, the only way to obtain the statue of the goddess? The mythical history only contemplates violence and cunning, not the possibility of an agreement based on the sharing human values.

The two protagonists are both creatures of myth, and destroyers of myth: they force myth from within. The value of fraternal love is both one of their instruments to force myth, and the means through which the gods show that they want to be redeemed from their own mythological image. In conclusion, the Goethean play may perhaps not be Greek, as Schiller said, ${ }^{43}$ but it is, from our point of view, definitively Euripidean.

\author{
Marco Duranti \\ University of Verona \\ Italy \\ marco.duranti@univr.it
}

\footnotetext{
${ }^{42}$ A. P. COTTRELL underlines the interiorization of the oracle in man (On speaking the good. Goethe's Iphigenie as "Moralisches Urphänomen". Modern Lmythanguage Quarterly 41 [1980] 162-180).

${ }^{43}$ In a letter to C. G. Körner (21 January 1802) Schiller defined Goethe's Iphigenie "erstaunlich modern und ungriechisch" (astonishingly modern and not Greek), pointing out the lack of dramatic action and the hypertrophy of the "inner life" of the protagonists (See BERGER [n. 28] 175). Schiller understood that Goethe strongly disempowered the dramaturgic effectiveness of the Euripidean plot, in order to focus on the interiority of the characters (see MAURER, K.: „Zwischen uns sei Wahrheit”: die Emanzipation der dramatischen Handlung von den Regeln der klassizistischen Intrigen-Führung in Goethes Iphigenie auf Tauris. Neohelicon 29 [2002] 193-217).
} 